\title{
The effect of isostatic pressing on the quality indicators of plant products (the example of Lonicera Caerulea L.)
}

\author{
Vladimir Sorokopudov ${ }^{1}$, Irina Zinoveva ${ }^{2}$, Olga Sorokopudova ${ }^{1}$, Alla Kuklina $^{3}$ \\ ${ }^{1}$ Russian State Agrarian University -K.A. Timiryazev MAA Moscow, Russia \\ ${ }^{2}$ Institute of Pharmacy, Chemistry and Biology Belgorod State National Research University Belgorod, Russia \\ ${ }^{3}$ FSBI The Tsytsin Main Moscow Botanical Garden of Academy of Sciences Moscow, Russia
}

\begin{abstract}
The results of studying quality indicators (organoleptic, physicochemical, microbiological) puree from the fruits of Lonicera caerulea L. (blue honeysuckle) before and after pressure treatment are presented. It was found that organoleptic and microbiological indicators meet the requirements established by the standard for these products. The content of organic acids in the puree during processing increases due to an increase in the level of lactic acid as a result of the destruction of sugars. The amount of vitamin $\mathrm{C}$ and sugars is reduced slightly. The content of anthocyanins undergoes the greatest changes, the amount of which decreases to a greater extent compared with other studied substances.
\end{abstract}

\section{Introduction}

The requirements of the modern market increase the needs of industry in new technologies that meet the needs of modern consumers, including those related to the processing of plant materials. As a variant of the new technology, a non-thermal method for pasteurization of food products using ultra-high pressure can be considered. Despite the fact that they studied the inactivation of microorganisms by high pressure at the end of the 19th century [1-3], interest in the industrial use of this phenomenon arose only at the end of the 20th century [3-4]. Currently, the technology of processing food products with high pressure in order to increase their shelf life is becoming increasingly developed abroad. Ultra-high pressure settings are successfully used in Europe, North America, Japan and New Zealand, and very rarely in Russia [3, 5-9].

Analysis of literary sources, as well as preliminary experimental studies, allow us to consider the technology of isostatic pressing as promising for processing raw materials of plant origin [1]. Non-thermal method of pasteurization of food products using ultra-high pressure is an environmentally friendly technology, the advantages of which include:

- the possibility of using for a wide range of products: meat and meat products, fish and seafood, milk and dairy products, vegetables, fruits and their processed products, etc.;

- the exclusion from the formulations of products subject to long-term storage, preservatives and additives that increase their shelf life;

- preservation of organoleptic properties (taste, color, smell, texture), nutritional value and a significant increase in the shelf life of processed products;
- cardinal destruction of microflora, including pathogenic microorganisms (Vibrio, Listeria, Esherihia coli, Campylobacter, Salmonella, etc.), which significantly affects the safety of food use

- compliance with modern environmental requirements;

- low energy consumption of non-thermal processing;

- the absence of deformation of processed food products, due to the uniform distribution of hydrostatic pressure (regardless of the volume and shape of the product), which reduces the processing time of the products.

The high-pressure food processing technology has been successfully applied to achieve sterilization of products while maintaining texture and taste [7], using a pressure in the range of 100-800 $\mathrm{MPa}$, a temperature of $20-80{ }^{\circ} \mathrm{C}$, and holding time up to 30 minutes. The results obtained are significantly different and superior to those that give traditional methods of preserving products.

However, there are a number of problems holding back the development of this technology using pressure. The main problem is the uncertainty in the choice of the physical parameters of the impact, since various combinations of pressure, temperature and holding time can give the same final result. In this regard, the selection of physical parameters of exposure and the development of isostatic pressing technology for plant products (fruits, berries and mushrooms) with an increased shelf life and high preservation of biologically active substances are relevant.

When choosing a plant product as the object of study, the following fact was taken into account. Berry crops are used as food and have been used as a dietary and medicinal product since ancient times. Their nutritional and biological value are determined by the content of vitamins, carbohydrates, organic acids, nitrous and 
tannins, and flavoring, coloring and aromatic substances contained in fruits and berries contribute to increased appetite [10]. However, they cannot be stored fresh for a long time while maintaining their quality characteristics, so they are subjected to various processing methods.

Blue honeysuckle (Lonicera caerulea L., family Caprifoliaceae) belongs to non-traditional berry crops and is valued for a very early fruiting period. In Central Russia, its fruits ripen 7-16 days before the ripening of wild strawberries and 20-30 days before blackcurrant. The advantages of this culture are annual productivity, fruit saturation with vitamins and their dietary qualities [11]. Honeysuckle fruits are extremely important in nutrition, since they are a source of vitamins such as C, P and provitamin $\mathrm{A}$, as well as biologically active substances, including anthocyanins with antioxidant activity. Our body is not able to synthesize many antioxidants, therefore, in modern environmental conditions, the human diet must necessarily contain bioflavonoids that increase the body's resistance to adverse environmental factors, including chemical carcinogens and radiation [12].

The fruits of Lonicera caerulea L. are very tender and can be stored fresh for a short period. At the same time, it is precisely for plant raw materials that such a concept as seasonality is characteristic. Therefore, this type of raw material is more processed, therefore, the development of new technologies to produce a product suitable for long-term storage, preserving to the maximum extent the organoleptic characteristics, nutritional and biological value characteristic of the feedstock, is an important modern task.

\section{Experimental}

The object of this study was puree from the fruits of Lonicera caerulea L. (blue honeysuckle), studied before and after pressure treatment.

When performing the work, the following research methods were used:

- the assessment of organoleptic indicators was performed according to GOST 32742-2014 [13];

- determination of vitamin $\mathrm{C}$ - according to GOST 24556-89 [14];

- quantitative determination of the sum of anthocyanins was carried out by a differentiated spectrophotometric method [15];

- determination of sugars - according to GOST 8756.13-87 [16];

- determination of titratable acidity - according to GOST ISO 750-2013 [17];

- microbiological indicators - according to GOST 30425-97 [18].

The aim of this work was to study the effect of isostatic pressing on the quality indicators of plant products (for example, Lonicera caerulea L.).

Tasks:

- to obtain experimental samples of puree from the fruits of Lonicera caerulea L., processed by isostatic pressing;
- to study quality indicators (organoleptic, physicochemical, microbiological) mashed potatoes from the fruits of Lonicera caerulea L. before and after pressure treatment.

\section{Results and discussion}

The developed storage technology of Lonicera caerulea L. using the isostatic pressing method includes the following operations:

- fruit sorting in order to remove impurities and damaged specimens;

- washing in running water;

- grinding to a puree state;

- packing in containers and packaging using a vacuum apparatus;

- treat with isostatic pressure of $400 \mathrm{MPa}$ for 30 minutes.

Puree from the fruits of Lonicera caerulea L., examined before and after isostatic pressure treatment. The organoleptic characteristics of puree met the requirements of GOST 32742-2014 [13] (Table. 1).

Studies to determine individual biologically active substances (Table 2) show that the content of vitamin C (ascorbic acid) slightly decreases during pressure treatment. Vacuum packaging eliminates the possibility of exposure to atmospheric oxygen on the processed product, thereby preventing the oxidation of ascorbic acid to dehydroascorbic acid. The rate of aerobic oxidation of ascorbic acid depends on the $\mathrm{pH}$ of the solution, reaching a maximum at $\mathrm{pH} 5$ and 11.5 . However, the fastest and most complete fragmentation occurs in an alkaline environment. Oxidative cleavage also occurs under anaerobic conditions, although more slowly. Slight destruction can be explained by the technology of processing honeysuckle fruits and preparing ready-made puree for pressure treatment.

The content of anthocyanins is significantly reduced when exposed to pressure. Due to the high electrophilicity of the chromenilium cycle, the structure and, accordingly, the color of anthocyanins and anthocyanidins is determined by their sensitivity to $\mathrm{pH}$ : in an acidic environment $(\mathrm{pH}<3$ ), anthocyanins (and anthocyanidins) exist in the form of pyrilic salts, when the $\mathrm{pH}$ increases to $\sim 4-5$, the hydroxide ion is added with the formation of a colorless pseudo base, with a further increase in $\mathrm{pH}$ to $\sim 6-7$, water is split off with the formation of the quinoid form, which, splits off the proton at $\mathrm{pH} \sim 7-8$ with the formation of phenolate, and finally, at $\mathrm{pH}$ above 8 , the quinoid phenolate hydrolyzes with rupture of the chromene cycle and the formation of the corresponding chalcone.

The bulk of sugars in the fruits of honeysuckle is represented by monosaccharides - glucose and fructose. Fructose is easily converted to glucose. Sugar content in puree from the fruits of Lonicera caerulea L. fruits decreases during storage (Table 3). This is due to the fact that under anaerobic conditions, the process of glucose breakdown proceeds intensively with the formation of lactate (lactic acid) as the final product, which leads to a decrease in the amount of sugars and an increase in total 
acidity. Acidity during storage of Lonicera caerulea L. increases due to an increase in the level of lactic acid as a result of the destruction of sugars.

Table 1. Characteristics of organoleptic quality indicators of puree from fruits of Lonicera caerulea L. before and after processing by pressure

\begin{tabular}{|c|c|c|c|}
\hline \multirow{2}{*}{$\begin{array}{c}\text { Name of } \\
\text { indicator }\end{array}$} & $\begin{array}{c}\text { Characteristic } \\
\text { according to GOST } \\
32742-2014\end{array}$ & \multicolumn{2}{|c|}{$\begin{array}{c}\text { Characteristic of the } \\
\text { studied samples }\end{array}$} \\
\cline { 3 - 4 } Appearance & $\begin{array}{c}\text { Homogeneous puree } \\
\text { processing } \\
\text { mass without } \\
\text { particles, fibers, peels, } \\
\text { seeds, stalks and } \\
\text { leaves }\end{array}$ & $\begin{array}{c}\text { after } \\
\text { proces } \\
\text { sing }\end{array}$ \\
\hline Taste and & $\begin{array}{c}\text { Corresponds } \\
\text { smell }\end{array}$ & $\begin{array}{c}\text { Well defined, inherent } \\
\text { in the taste and smell } \\
\text { of the fruits of which } \\
\text { puree mass is } \\
\text { prepared. Foreign } \\
\text { smack and odor not } \\
\text { allowed }\end{array}$ & Corresponds \\
\hline Consistency & Puree fluid mass & Corresponds \\
\hline Colour & $\begin{array}{c}\text { Homogeneous } \\
\text { throughout the mass, } \\
\text { inherent in the colour } \\
\text { of the used fruits }\end{array}$ & Corresponds \\
\hline
\end{tabular}

Table 2. Content of biologically active substances in puree from fruits of Lonicera caerulea L. before and after processing by pressure

\begin{tabular}{|c|c|c|}
\hline \multirow{2}{*}{$\begin{array}{c}\text { Biologically active } \\
\text { substances }\end{array}$} & \multicolumn{2}{|c|}{ Content, $\mathrm{mg} \%$} \\
\cline { 2 - 3 } & $\begin{array}{c}\text { before } \\
\text { processing }\end{array}$ & $\begin{array}{c}\text { after } \\
\text { processing }\end{array}$ \\
\hline Vitamin C & $60,50 \pm 0,20$ & $56,98 \pm 0,26$ \\
\hline Anthocyanins & $330,89 \pm 3,11$ & $256,04 \pm 5,97$ \\
\hline
\end{tabular}

The microbiological characteristic gives the most complete picture of the storage process of puree from fruits of Lonicera caerulea L. before and after pressure treatment. The development of microorganisms is one of the main reasons for reducing the quality of the food product during storage. The source of infection of the products is mainly raw materials. Seeding can also occur during the preparation of raw materials, their processing, with insufficiently thorough washing of equipment, with emergency delays in the process.

Given that puree from the fruits of Lonicera caerulea L. is a product of long-term storage, special attention should be paid to microbiological purity [19]. In this regard, studies have been conducted to determine a number of microbiological parameters characteristic of this group of products. For puree from the fruits of Lonicera caerulea L., during microbiological studies, the following microorganisms were analyzed: aerobes (industrial sterility), anaerobes, lactic acid bacteria, yeast and fungi. The microflora was determined for puree from the fruits of Lonicera caerulea L., processed in vacuum (control) on the day of its preparation. The study of Petri dishes with microflora seeded showed that in the puree, not processed by physical action (vacuum, pressure), 3 groups of microorganisms are seeded (Table 4).
Among aerobes and facultative aerobes, Bacillus subtilis, whose colonies are pinkish in color, smooth, shiny, is most common. The largest number of microorganisms was detected during plating on Blikfeld's medium: before the treatment puree revealed 111-104 colonies per $1 \mathrm{~g}$. Colonies, typical for this medium, are white, shiny, very small. Morphologically, we have identified as representatives of the genus Lactobacter. On Saburo's medium, the most common microorganisms were yeast; from fungi, they were noted in the sowing from the fruits of Lonicera caerulea L. Rhizopus nigricans Ehr., Which causes such a disease of the fruit as gray mold.

Table 3. Sugar and organic acid content in puree from fruits of Lonicera caerulea L. before and after pressure treatment

\begin{tabular}{|c|c|c|}
\hline \multirow{2}{*}{ Name of indicator } & \multicolumn{2}{|c|}{ Content, \% } \\
\cline { 2 - 3 } & $\begin{array}{c}\text { before } \\
\text { processing }\end{array}$ & after processing \\
\hline Sugars & $12,84 \pm 0,23$ & $11,45 \pm 0,18$ \\
\hline Acidity & $1,99 \pm 0,15$ & $2,13 \pm 0,10$ \\
\hline
\end{tabular}

Table 4. Dynamics of microflora in puree of Lonicera caerulea L. fruits before and after pressure treatment

\begin{tabular}{|c|c|c|c|}
\hline \multirow[b]{2}{*}{$\begin{array}{l}\text { Pressure/p } \\
\text { rocessing } \\
\text { time, min }\end{array}$} & \multirow[b]{2}{*}{ Microorganisms } & \multicolumn{2}{|c|}{ Content, colonies/g } \\
\hline & & $\begin{array}{c}\text { before } \\
\text { processing }\end{array}$ & $\begin{array}{c}\text { after } \\
\text { processi } \\
\text { ng }\end{array}$ \\
\hline \multirow{3}{*}{$400 / 30$} & Aerobes & $30 \times 10^{4}$ & $1 \times 10^{4}$ \\
\hline & Lactic acid bacteria & $111 \times 10^{4}$ & 0 \\
\hline & Mushrooms and yeast & $2 \times 10^{4}$ & 0 \\
\hline
\end{tabular}

Exposure to a pressure of $400 \mathrm{MPa}$ with an exposure of 30 minutes led to the complete inactivation of lactic acid bacteria and fungi. Sowing of Bacillus subtilis is detected on a nutrient medium in an amount of up to 1 colony, which fully complies with GOST 30425-97 [19] for products of the type under study. This information is fully consistent with foreign literature that describes the inactivation of Bacillus subtilis spores under pressure from $6 \mathrm{MPa}$.

\section{Conclusion}

Thus, it was found that in puree from the fruits of Lonicera caerulea L., which was processed with high pressure (400 MPA, exposure $30 \mathrm{~min}$ ), according to organoleptic characteristics, it meets the requirements of the standard. The amount of vitamin $\mathrm{C}$, as well as the sugar content in puree, is slightly reduced. The organic acid content of puree storage is increased by increasing the level of lactic acid as a result of the breakdown of sugars. To a greater extent during storage, a decrease in the number of anthocyanins occurs.

Exposure to a pressure of $400 \mathrm{MPa}$ with an exposition of $30 \mathrm{~min}$ of puree from the fruits of Lonicera caerulea $\mathrm{L}$. leads to complete inactivation of lactic acid bacteria, fungi and yeast and a decrease in the number of aerobes, namely B. subtilis, by 30 times. 


\section{REFERENCES}

1. V.N. Sorokopudov, A.G. Kuklina, N.I Myachikova., and I.G. Movchan, "Innovative technologies of healthy nutrition products", (Publishing House of FSBEI HE MichGAU, Michurinsk: p. 95-100, 2015)

2. B.H. Hite, N. I. Giddings, and C. E. Weakly, Morgantown. Bull. W.V. Univ. Agric. (Exp. Stat Morgantown), 146, 1-65, (1914)

3. C.E. Leadly and A. Williams, New Technologies Bull, 14, Mar., 39-45, (1997)

4. K. Autio, "Fresh novel foods by high pressure", VTT Symposium: Technical Research Center of Finland, p. 199-201, (1998)

5. H. Royer, Arch. Phisiol. Normale Pathol, 7, 12-19, (1895)

6. B.H. Hite, "Morgantown. Bull. W.V. Univ. Agric, (Exp. Stat Morgantown), 58,15-35, (1898)

7. D. Farr, Trends Food Sci. Technol. Int. ,. 1, 75-80, (1995)

8. D. Robert, New Technoogy, 9, 39-55, (1993)

9. G. Tewari, D.S. Jayas, and R.A. Holley, Science des Aliments, 19, 619-661, (1999)

10. V.N. Sorokopudov, O.A. Sorokopudova, A.G. Kuklina, and N.I. Myachikova, “ Wild berry crops - a source of biologically active substances as an essential component of human nutrition and health", in Environmental aspects of human, animal and plant life (Publishing House "Belgorod" NRU BelSU, Belgorod, p. 121-139, 2017)

11. V.N. Sorokopudov, A.G. Kuklina, and M.T. Upadyshev, Varieties of edible honeysuckle: biology and the basics of cultivation. Moscow: FSBSI RFIHN, (2018)

12. A.G. Kuklina, V.N. Sorokopudov, M.T. Upadyshev, O.A.
Sorokopudova, and G.A Prishchepina, Bulletin of the Russian Agricultural Science, 5. p. 41-45, (2017)

13. GOST 32742-2014. Semi-finished products. Canned fruit and vegetable purees aseptically. Specifications (as amended), (Standartinform, Moscow, 2014)

14. GOST 24556-89. Products of processing fruits and vegetables. Methods for determination of vitamin C, Moscow: PPC Standards Publishing House, (2003)M. Giusti and R.E. Wrolstad, "Characterization and Measurement of Anthocyanins by UV-Visible Spectroscopy", Current Protocols in Food Analytical Chemistry, F1.2.1-F1.2.13, (2001)

15. GOST 8756.13-87. Products of processing fruits and vegetables. Methods for the determination of sugars, Moscow: Standartinform, (2010)

16. GOST ISO 750-2013. Products of processing fruits and vegetables. Determination of titratable acidity (Reprint), Moscow: Standartinform, (2018)

17. GOST 30425-97. Canned food. Method for determining industrial sterility, Moscow: Standartinform, (2011)

18. J.C. Cheftel, Review: Food Sci. Technol. Int., 1, p. 85-90, $(1995)$ 